\title{
A First Nations-led social innovation: a moose, a gold mining company, and a policy window
}

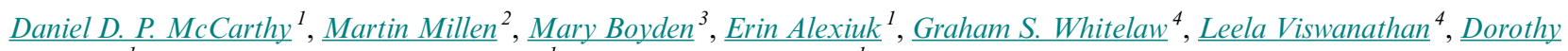
Larkman $^{1}$, Giidaakunadaad (Nancy) Rowe ${ }^{1}$ and Frances $R$. Westley ${ }^{1}$

\begin{abstract}
A recent focusing event involving the death of a moose in the Dome open-pit mine in the community of Timmins, in northern Ontario, Canada has triggered the opening of a policy window related to the governance of resource extraction by indigenous peoples. This event, combined with several other factors, including: (1) the high price of gold; (2) a mining company seeking to demonstrate corporate social responsibility to repair its international reputation with indigenous peoples by supporting an innovative, local Indigenous-led initiative; and (3) a new policy context, including Supreme Court of Canada decisions and provisions in the updated Ontario Mining Act, that require meaningful consultation with indigenous peoples has led to the emergence of a indigenous peoples-led collaborative, social innovation. This policy window allowed for the formation of an unprecedented council of indigenous knowledge holders (elders) and traditional practitioners to help inform mine restoration and practice as well as to foster the resurgence of traditional language and culture in local indigenous communities. Here, we document this unprecedented social change opportunity.
\end{abstract}

Key Words: critical indigenous research; indigenous-led innovation; policy window; social innovation; traditional knowledge

\section{INTRODUCTION}

Social innovation is an initiative, product, process, or program that profoundly changes the basic routines, resource and authority flows or beliefs of any social system. Successful social innovations have durability, make broad impact, and cross scales, as defined by Social Innovation Generation ( $\mathrm{SiG})$. Whereas social innovation has recognizable stages and phases, achieving durability and scale is a dynamic process that requires both emergence of opportunity and deliberate agency, and a connection between the two. The capacity of any society to create a steady flow of social innovations, particularly those which reengage vulnerable populations, is an important contributor to overall social and ecological resilience (Westley 2008). We utilize the following definition of resilience:

the capacity of an ecosystem to tolerate disturbance without collapsing into a qualitatively different state that is controlled by a different set of processes. A resilient ecosystem can withstand shocks and rebuild itself when necessary. Resilience in social systems has the added capacity of humans to anticipate and plan for the future (Resilience Alliance 2012).

Although this view on social-ecological systems provides useful insights, it flies in the face of indigenous ways of knowing and "natural law" in terms of the relationship between humans and the natural world. This divergence is beyond the scope of the work at hand, but needs to be noted and explored further in subsequent work. Innovations tend to fall into two general categories: incremental and radical (Biggs et al. 2011). The latter are often the result of a window of opportunity or policy window (Kingdon and Thurber 1984, Kingdon 1995, Michaels et al. 2006) triggered by a focusing event (Birkland 1997, Michaels et al. 2006).

A recent focusing event involving the death of a moose in the Dome open-pit mine in the community of Timmins, in northern Ontario, Canada (see Fig. 1) has triggered the opening of a policy window related to the governance of resource extraction by indigenous peoples. This event, combined with several other factors, including: the high price of gold; a mining company seeking to demonstrate corporate social responsibility to repair its international reputation with indigenous peoples; and a new policy context, including Supreme Court of Canada decisions and provisions in the updated Ontario Mining Act, that require meaningful consultation with indigenous peoples has led to the emergence of a indigenous peoples-led collaborative, social innovation. This policy window allowed for the formation of an unprecedented council of indigenous knowledge holders (elders) and traditional practitioners to help inform mine restoration and practice as well as to foster the resurgence of traditional language and culture in local indigenous communities. Here, we document this unprecedented social change opportunity.

We provide the policy and case study context as well as a review of the relevant literature and development of the authors' conceptual framework, followed by an overview of our decolonizing, participatory action research methodological approach, data-gathering, and analysis methods. We then present our findings, documenting this indigenous peoples-led collaborative, social innovation as a policy window. The implications of our findings are presented for both the case study and for the discourse on social innovation. Finally, we provide recommendations and conclusions.

\section{BACKGROUND}

Contemporary colonization of indigenous peoples in Canada Canada continues to be challenged by colonial interests of the past and present that have marginalized its indigenous peoples. Indigenous peoples' capacity to engage in determining the nature and extent of development on their traditional territories is limited by socioeconomic conditions that fall below average Canadian levels of employment, family income, social assistance, education, housing, and life expectancies. Canada's human rights reputation continues to deteriorate, as documented in a United 
Nations review for its failure to address the devastating conditions in indigenous communities (Office of the High Commissioner for Human Rights 2012). The National Chief of the Assembly of First Nations, A-in-chut (Shawn) Atleo, in speaking about the need to address these conditions for Canada's indigenous peoples, argues that "the alternative, the status quo, is brutal" (Ibbitson 2011). This is more than simple hyperbole. The 2006 Canadian national census recorded the following statistics that speak directly to these appalling conditions: the employment rate of indigenous peoples was $14.8 \%$, compared with $6.6 \%$ nationally; indigenous peoples living in Canada earned an average of CAD $\$ 23,888$ per year in 2006, compared with CAD $\$ 35,872$ for nonindigenous Canadians; indigenous children living on reserves receive, on average, approximately $22 \%$ less in terms of social assistance than nonindigenous children; indigenous peoples are four times as likely to live in crowded dwellings as nonindigenous Canadians; indigenous children are eight times as likely to be taken into care than their nonindigenous counterparts; and, collectively, indigenous peoples living in Canada are twice as likely to live in poverty than nonindigenous Canadians (Statistics Canada 2008). These multiple structural social and economic conditions reflect the ongoing colonization and resultant marginalization of indigenous peoples living in Canada. These conditions tend to limit indigenous peoples' abilities to foster and lead positive social change and social innovation toward sovereignty and self-determination and to maintain their culture, language, and traditional and spiritual practices. The need for fundamental social change that alters basic resource, authority, and value structures or systems is clear.

Fig. 1. Map of Timmins, Ontario, Canada

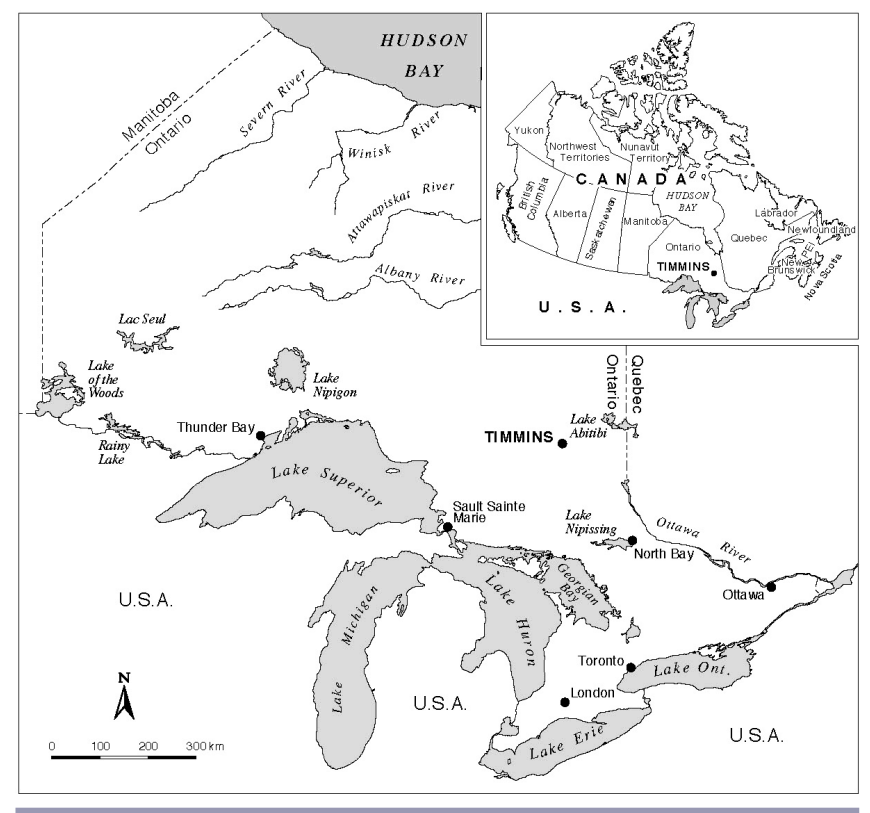

\section{Situating the research team}

In keeping with indigenous methodology, we briefly describe the research team and their research story to situate or position them (Smith 1999, Johnson 2008, Wilson 2008, Kovach 2010, Absolon 2011). The research team includes indigenous knowledge holders and traditional practitioners from various First Nations communities in Ontario, Canada, a representative of a large private-sector mining corporation, and academic researchers, that is, professors, $\mathrm{PhD}$ students, and master's students, of mixed European heritage and indigenous heritage. We have come together over the last four years to work collaboratively on this initiative, seeking to find respectful, reciprocal, and responsible ways to work together and to integrate our various knowledges. As a research team, we are hopeful that the social and environmental injustices that we, as settler Canadians, have propagated and continue to propagate on our indigenous brothers and sisters can be more effectively acknowledged and addressed through a critical indigenous and social innovation lens. We believe that the kind of systemic and structural change required to address these injustices is possible and begins with us striving to learn from indigenous peoples to begin a reconciliation through a mutual acceptance of difference (Jones and Jenkins 2008).

\section{Case study context: Timmins, Ontario}

Timmins is a city in northeastern Ontario, Canada, on the Mattagami River. At the time of the 2011 Canadian census, the population of Timmins was 43,165. At 2,961.52 square kilometers, it was Canada's largest municipality as measured by area until 1995, and Ontario's largest until 2001. The municipality of Timmins was established in 1912 following major gold discoveries in the area, and to this day it remains a predominantly mining-based community. However, archaeological and historical studies indicate that the first peoples to settle in the Timmins area were nomadic tribes including Ojibwe, Cree, and Algonquin peoples dating back to 7,000 B.C. Although they are still contested, several Treaties, including Treaty 9 (1905-1906; 1929, 1930 adhesions) within which Timmins lies, formalized settlement on the lands and outlined protections for certain Aboriginal rights

Several indigenous communities surround Timmins today; these include members of the Ojibwe, Cree, and Algonquin First Nations. In particular, our discussion focuses on the communities represented by the Wabun Tribal Council and the Wahgoshig First Nation. The Wabun Tribal Council includes the communities of Beaverhouse, Brunswick House, Chapleau Ojibwe, Flying Post, Matachewan, and Mattagami. The Council was incorporated in October 1989 as the Department of Indian and Northern Affairs Canada (INAC) transferred the coordination and delivery of community services to the local level. Wabun represents its member indigenous communities at various local and regional forums ranging from indigenous peoples' financial institutions to police services boards. The Council also represents community interests in dealings with municipal, provincial, and federal government programs and initiatives, such as land-use planning, Local Health Integration Networks (LHIN), and other issues as directed by the Chiefs of the involved communities - such as resource development agreement negotiations. The Wahgoshig First Nation, an independent Algonquin and Cree community in Treaty 9 , also holds traditional territory in the Timmins area.

\section{Policy context}

Duty to consult

Treaty rights are defined through historical and modern-day treaties signed between indigenous peoples and the Crown. (The Crown in this case can be described as a symbol of the power of 
the state which is vested in the British Monarch, where she is the ornamental head of state in most Commonwealth countries.) Indigenous peoples' traditional territories in Canada generally include federal reserves as well as extensive lands used and occupied historically by indigenous peoples. These lands may be provincial Crown or privately held lands. A number of key decisions of the Supreme Court of Canada, dealing with resource and land management over the past 20 years, have changed the relationship of indigenous peoples living in Canada with both governments and private resource developers (Asch and Macklem 1991, Lawrence and Macklem 2000, Isaac and Knox 2003). For example, in 2004, the Supreme Court clarified that the Crown is required to consult with indigenous peoples "when the Crown has knowledge, real or constructive, of the potential existence of the [indigenous peoples'] right or title and contemplates conduct that might adversely affect it" (Haida Nation v British Columbia 2004). The duty to consult flows from the honor of the Crown and requires "meaningful" consultation that takes "steps to avoid irreparable harm or to minimize the effects of the infringement" on identified rights of indigenous peoples or treaty rights (Haida Nation v British Columbia 2004). The required level of consultation is determined through the strength of the indigenous peoples' claim to the right and the magnitude of the infringement on that right by the proposed undertaking (Haida Nation v British Columbia 2004).

There is a broad spectrum of interpretation of the requirements for the Crown's duty to consult in Canada (Asch and Macklem 1991, Lawrence and Macklem 2000, Isaac and Knox 2003). Recognizing that high-level decisions and policy can impact operational-level activities, the Supreme Court clarified that meaningful consultation occurs at the strategic level (Haida Nation $v$ British Columbia 2004). In Ontario, the outcome of the duty to consult primarily involves the circulation of development proposals to indigenous peoples who would be impacted by proposed development (Government of Ontario 2006). Land-use planning and environmental legislation such as the Ontario Environmental Assessment Act and the Water Resource Act govern the majority of developments in Ontario and are often accompanied by detailed circulation requirements (Legislative Assembly of Ontario 2010a, 2012).

It should be noted that the ambiguous language in both the Supreme Court decisions and treaties emphasizes the need for thorough consultation to ensure good-faith efforts are made by both the Crown and indigenous peoples to reach consensus. However, in regions facing high levels of pressure from development, indigenous peoples are often inundated with requests to review land-use planning and environmental assessment development proposals.

\section{Ontario's Mining Act}

Ontario's original Mining Act, first passed in 1873 and significantly amended in 1906, reflected a resource-based economic regime in which the exploitation of natural capital was viewed as crucial to the economic development of Canada as a nation. It is not surprising, then, that the Mining Act was systematically designed to encourage and facilitate mining, and conversely, to avoid and/or preclude any significant opposition to this economic activity. A "free-entry" system is embodied in the legislation, privileging the rights of mining companies to explore and exploit mineral resources, while underemphasizing public participation. Mining Watch (2012) describes four key features of this approach:

- the right of prospectors to enter lands containing Crownowned minerals to undertake mineral exploration;

- the right of prospectors to acquire mineral exploration rights by properly staking a claim and having it recorded with the mining recorder;

- the exclusive right of the claim holder to carry out further exploration within the area covered by the claim; and

- the right of the claim holder to obtain a mining lease, that is, the tenure instrument required to undertake mineral production, provided proper procedures and requirements have been complied with.

In 2010, the Ontario government again amended the Mining Act, claiming to have "modernized" the statute. However, it has been argued that these amendments have done little to address the flaws of the old regime (Mining Watch 2012). The amendments passed in 2009 left the characteristics of a free-entry system largely intact, with minimal modifications. The amended Act has provided for some increased transparency and related participatory rights; however, opportunities for public participation in the early stages of the process are limited or uncertain. With respect to the rights of indigenous peoples, the purpose clause of the Mining Act has been altered to state the following:

The purpose of this Act is to encourage prospecting, staking and exploration for the development of mineral resources, in a manner consistent with the recognition and affirmation of existing [rights of indigenous peoples] and treaty rights in section 35 of the Constitution Act, 1982, including the duty to consult, and to minimize the impact of these activities on public health and safety and the environment (Legislative Assembly of Ontario 2010b).

The amended purpose clause reflects a critical reference to a requirement to consult indigenous communities, acknowledging section 35 of the Constitution Act as well as the Crown's duty to consult. However, the language used in the amended Act opens the window for the Ontario government to delegate consultation responsibilities to the private sector (Legislative Assembly of Ontario 2010b, Pardy and Stoehr 2011). Yet, although the Crown may be legally permitted to delegate consultation responsibilities, the duty to ensure meaningful consultation rests with the Crown, not the private sector (Haida Nation v British Columbia 2004, Simons and Collins 2010, Pardy and Stoehr 2011). The 1990 Sparrow decision clarified that if consensus is not reached through consultation, the Crown must justify projected infringements, act to mitigate potential impacts, and ensure fair compensation is made available for any rights infringements $(\mathrm{R}$. v. Sparrow 1990, Simons and Collins 2010. Yet, the amended Mining Act lacks explicit reference to the duty to accommodate where there are known infringements on the rights of indigenous peoples and treaty rights as has been directed by Canada's Supreme Court (R. v Sparrow 1990, Haida Nation v British Columbia 2004, Taku River Tlingit First Nation v British Columbia 2004). 
In conclusion, despite this lack of explicit reference, the cited case law suggests that the addition of the duty to consult in the amended Mining Act should be interpreted as direction to negotiate in good faith to understand potential infringements and act in a meaningful way to reduce or mitigate perceived impacts to be in accordance with Supreme Court direction.

\section{Conceptual/theoretical context}

Social innovation and complex social-ecological systems Social innovation refers to new concepts, strategies, initiatives, products, services, processes, or organizations that meet pressing social needs and profoundly change the basic routines, resource and authority flows, or values and beliefs within the social system in which they arise (Westley et al. 2006, Young Foundation 2006, Biggs et al. 2010). Any process of social innovation consists of two key dynamics: (1) "bricolage," or recombining existing and new ideas to form something novel (Levi-Strauss 1962, Arthur 2009, Biggs et al. 2010), and (2) "diffusion" or "contagion" models of the adoption or spread of new ideas or inventions (Rogers 1995, Westley et al. 2005, Biggs et al. 2010). McKeown (2008) describes two broad categories of innovations: (1) incremental innovation, and (2) radical innovation.

This case study contributes to research that has applied systems thinking to building resilience and fostering adaptive capacity, social learning, and especially social innovation within complex social-ecological systems (Gunderson et al. 1995, Berkes and Folke 1998, Kay et al. 1999, Gunderson and Holling 2002, Berkes and Folke 2003, Waltner-Toews et al. 2004, Armitage 2005, Westley et al. 2005, Walker et al. 2006, Westley 2008, Biggs et al. 2010, McCarthy et al. 2011). Resilience thinkers describe the dynamics of complex, linked social-ecological systems as having four distinct phases organized around an "adaptive" or "panarchy" cycle.

The panarchy cycle is a model that originally applied to ecosystem dynamics but in recent decades has been used to describe a fourphase - exploitation, conservation, release, and reorganizationcross-scalar set of dynamics exhibited by complex, linked social and ecological systems (Gunderson et al. 1995, Holling 2001, Gunderson and Holling 2002, Walker and Salt 2006). The model can be described in terms of "front-loop," that is, exploitation to conservation phase and "back-loop," that is, release to reorganization phase, dynamics. The front loop represents a conventional "s-curve" of development either in ecological or economic systems in which the system evolves from a highly flexible and adaptive but largely inefficient system to a highly efficient but brittle system. The back loop is a much more uncertain and temporally shorter dynamic in which energy, material, and information may be released from the collapse of the rigid conservation phase and the system begins to reorganize. This back loop is highly uncertain but also generally ripe with opportunities. Systems that can continuously navigate through these four cycles and two loops, and that exhibit the ability to deal with stress and still maintain their organization, are said to be resilient (Gunderson et al. 1995, Holling 2001, Gunderson and Holling 2002, Walker and Salt 2006). A key part of a complex social-ecological system's resilience is its ability to innovate (Westley 2008, Biggs et al. 2010). The relationship between incremental and radical innovation can be understood in the context of the panarchy or adaptive cycle (Holling 2001,
Gunderson and Holling 2002, Biggs et al. 2010). The front loop of the panarchy cycle can be usefully thought of as being characterized by incremental innovation that reinforces the current system or current trajectory of change (Biggs et al. 2010). The back loop may be conceptualized as being characterized by discontinuous change, often in the form of a collapse and reorganization of social structures, which can lead to a window of opportunity for radical innovation (Biggs et al. 2010). Such windows of opportunity in the context of environmental management or linked social-ecological systems have been described as policy windows (Kingdon and Thurber 1984, Kingdon 1995, Michaels et al. 2006).

Policy windows and the social innovation process

Policy windows are ephemeral opportunities during which the adoption of new or innovative ideas or policies is greater than usual (Solecki and Michaels 1994). As Kingdon (1995:166) indicates, policy windows "open infrequently, and do not stay open long, but despite their rarity, the major changes in public policy result from the appearance of these opportunities." Kingdon (1995) describes how three related aspects or "streams" of a policy or social change process - problem, political, and policy-converge to move an innovative idea onto the public policy agenda and toward potential governmental action. The problem stream refers to how decision makers learn about new issues or ideas and how they define and understand their evolution. The political stream refers to the political climate and public opinion with reference to the issue. The policy stream includes the set of potential solutions to the problem (Michaels et al. 2006).

Kingdon (1995) uses the term "coupling" to describe when these three major streams converge, and finds that these independent streams "flow" through the system all at once. They become coupled or emerge onto the policy agenda when a window of opportunity is opened (Thurber 2003). Kingdon argues that an issue, idea, or innovation is most likely to reach the public agenda when public problems, policy alternatives, and political opportunities intersect; that is, when a problem can be clearly identified, when valid alternative options already exist or are emerging, and when there is political will to enact the change. Furthermore, these windows generally present themselves when there is a major incident or "focusing event" that requires action. The idea of a focusing event is used to describe a sudden, uncommon event such as a disaster or a crisis that leads to a policy or social change (Birkland 1997, Michaels et al. 2006).

In the context of a social innovation process, a policy window can be seen to be a "back-loop" phenomenon that can trigger radical innovation (Biggs et al. 2010). Therefore, a focusing event can be seen to be a "tipping point" or "bifurcation point" in which a brittle system is seen to collapse. In the same way, the "coupling" of the three streams that Kingdon $(1984,1995)$ discusses can be seen to be a phenomenon associated with the "reorganization" phase of the panarchy cycle, setting the stage for a new and emerging system state (Biggs et al. 2010).

\section{METHODOLOGY}

This project was conceived, developed, and implemented collaboratively with traditional practitioner Martin Millen; Porcupine Gold Mines' Indigenous Community Relations 
Manager Mary Boyden; and researchers from the University of Waterloo and Queen's University, in Ontario, Canada. Over the last three years, academics from the University of Waterloo and Queen's University have forged a strong, collaborative relationship with Martin Millen, Mary Boyden, and an unprecedented group of indigenous knowledge guardians from across Canada. The university-based research team was invited to participate in this project to provide some expertise in environmental policy, mapping, and social innovation. It was recognized early on by Martin Millen and Mary Boyden that the development of Anishanaabe Maamwaye Aki Kiigayewin (AMAK) - a name taken from an Ojibwe phrase meaning "all people coming together to heal the Earth" - to address the effects of mining in Timmins was a unique undertaking that had the potential to be system-changing. Daniel McCarthy was then invited to help document this project as a case study of social innovation.

The authors' methodology attempts to apply a decolonizing approach to research through the application of participatory action research to a case study. Recent work on "decolonizing" indigenous research methodologies, mainly by indigenous scholars, is pointing to the need for researchers to reflect critically upon how their research reinforces existing colonizing processes (Smith 1999, Wilson 2008). Decolonizing methodologies have an explicit aim to advance social justice through the decolonization of dominant knowledge paradigms; this is a holistic, iterative, and inclusive approach that is situated in the wider context of indigenous self-determination (Smith 1999, Steinhauer 2002, Johnson 2008, Wilson 2008, Kovach 2010). Perhaps the most fundamental principle of a decolonizing approach is that it is conducted with or at the request of indigenous peoples. In summary, "the research done is the research the community wants done" (Heckenberg 2011:113). This community-directed approach flows from the acknowledgement of the "collective memory of imperialism" perpetuated by research on and about indigenous peoples communicated through the dominant paradigm (Smith 1999:1).

Throughout this collaborative research process, the universitybased researchers have sought to be allies and supporters in the development of this project as an indigenous peoples-led initiative. In keeping with the decolonizing aims of this work, the authors continually reflected critically upon both their roles and the relationship between indigenous and nonindigenous colleagues. There were consistent check-ins with indigenous colleagues to ensure the role of the university researchers was supportive, making all of the authors conscious of, and engaged in, unraveling existing colonizing practices in conducting research and exchanging knowledge. For example, this was written as part of the educational aims of AMAK, intended to bring awareness of such work to academia, and particularly to indigenous students. Daniel McCarthy wrote the first version of the paper and circulated it to academic colleagues for feedback. Then, it was sent to Martin Millen and Mary Boyden along with AMAK's indigenous scholars. Significant changes were made after this step as Daniel McCarthy was taught how to further decolonize this project by choosing indigenizing language (Smith 1999) and content that balances the perspectives of both the nonindigenous and indigenous peoples involved in this work. The work went through a process of sanctioning by the indigenous knowledge guardians at AMAK's center, which included a presentation of the material by a trusted indigenous scholar, before it was submitted for publication. In this way the authors, as indigenous and nonindigenous scholars, have collaborated under a "shared imagination and a new language" at the intersection of western and indigenous knowledge in a shared space for activism, advocacy, and resistance (Denzin et al. 2008:15). The involvement of the nonindigenous members of the university team took the form of participatory action research. As described by Whyte (1991:20), "in participatory action research, some of the people in the organization or community under study participate actively with the professional researcher throughout the research process from the initial design to the final presentation of results and discussion of their action." Single, as compared with comparative, case studies involve the exploration of a single entity or phenomenon bounded by an event and process. As a research strategy, case studies are used in many situations to "improve our knowledge of individual, group, organizational, social, political, and related phenomena" (Yin 2003:1). The need for case studies arises out of the desire to understand complex social phenomena; a case study allows investigators to retain the holistic and meaningful characteristics of real-life events, such as organizational and social change processes (Yin 2003). Case studies are useful as they incorporate both narrative and empirical information; thus, conducting the Timmins case study adds legitimacy to the events and experiences witnessed in a framework that is acceptable in mainstream qualitative research.

Qualitative data for this work were gathered through participant observation at a series of project meetings, public meetings, and ceremonies during the ongoing collaboration with AMAK. Participant observation refers to "research that involves social interaction between researcher and informants in the milieu of the latter, during which data are systematically and unobtrusively collected" (Taylor et al. 1984:15). This interpretation of participant observation "assumes that knowledge develops from experience, particularly the experience of social-political action" (Neuman 2000:24). The collaborative relationship between the university-based team and indigenous partners formed during the research period from July 2009-January 2013. During this time, the authors and other participants engaged in various forums including eight face-to-face meetings, two training sessions, one public meeting, and three multiple-day traditional conferences. All practical and scholarly outputs of this research were cowritten by and/or vetted by the authors.

\section{ANALYSIS}

The Timmins policy window and Anishanaabe Maamwaye Aki Kiigayewin as an emerging social innovation

Findings are presented in the context of the case study as the emergence of the three streams of the policy window, that is, the problem, political, and policy streams; and then as the coupling of the three streams as a result of the focusing event, ultimately leading to the emergence of this potential social innovation.

\section{Problem stream}

The price of gold has seen an exceptionally dramatic rise in recent years. In particular, between 2006 and mid-2011, the market price of gold rose by more than $150 \%$, from an average of U.S.\$833 to about U.S.\$1,225 per ounce, and it hit a high of about U.S.\$1,557 
(Fig. 2). The rising gold price served as a stimulus to gold producers. World gold production rose strongly from the 1980s2002. It became difficult for global supply to keep up with demand. The high price of gold makes up part of the problem stream, in that a high price, and associated rising profits, encourages gold mining companies to explore and exploit sites considered noneconomic or marginal in previous, low-price regimes.

In the case of the Porcupine Gold Mines (PGM) in Timmins, Ontario, Goldcorp, the world's second-largest gold producer, acquired $51 \%$ of the Porcupine Joint Venture (PJV) from Placer Dome in May 2006. In 2007, Goldcorp acquired the remaining 49\%. The Porcupine operation consists of the Hoyle Pond Underground, the Pamour Open Pit, and the Dome Underground, along with a central milling facility. The properties have produced more than 16 million ounces of gold since production began in 1910 . The operating properties, combined with extensive and highly prospective land holdings, are strategically located in one of the world's great gold producing areas. The total PGM property area is approximately 38,000 ha of mining claims (Goldcorp 2012). Some of these properties, given new technologies and the high price of gold, became economically feasible to remine. Other properties included in this package are solely restoration or rehabilitation sites. As discussed earlier, both the Crown's legal duty and provisions in the Mining Act require consultation with indigenous peoples in both the active mining and restoration properties. This also feeds into the political and solution streams in that soaring profits have allowed Goldcorp to explore unusual and potentially innovative projects, such as this initiative.

\section{Political stream}

Along with the high price of gold and Goldcorp's international financial success, another key aspect to the problem stream in this case is the challenges that have characterized Goldcorp's relationship with indigenous peoples in south and central America. In particular, there have been issues with Goldcorp's Marlin mine, in Guatemala's western highlands, which began operations in 2005 and is licensed to continue until 2015. Swedish and Canadian investors and investment research providers visited the Marlin Mine in February 2008; following the visit, the investor group filed a shareholder resolution to Goldcorp's annual general meeting requesting an independent human rights assessment (HRA). The resolution did not require a vote, as Goldcorp quickly agreed to undertake the assessment. The full assessment was presented in the spring of 2010, and contained a long list of recommendations for the company to implement. Some weeks later, Goldcorp unveiled a package of measures based on the assessment, providing a response to every point listed. Subsequently, Goldcorp published two updates providing details on implementation of the recommendations. The vast majority of the recommendations were implemented by late 2011, when Goldcorp issued its final update.

Meanwhile, on May 20, 2010, the Inter-American Commission on Human Rights (IACHR) had issued precautionary measures to the Government of Guatemala to suspend operations pending a social impact assessment consisting of further investigation into alleged human rights and environmental abuses. On June 23, 2010, the Government of Guatemala advised the IACHR that it would initiate the applicable administrative process under the laws of
Guatemala to determine whether IACHR's suggested suspension of Marlin operations was warranted. After extensive review of the available data and reports from the responsible governmental ministries, including the Ministries of Environment and Health and Social Welfare, the Government of Guatemala issued a resolution on July 8, 2011 declaring that the Marlin Mine was operating in compliance with the law and that there was no basis for suspending operation of the mine. Additional government investigations were conducted; in December 2011, the IACHR issued an amendment to the precautionary measures, and the request to suspend operations at Marlin was lifted. However, several local NGOs, with the support of international groups such as Amnesty International, denounced ongoing human rights violations near the Marlin mine. In 2010, Amnesty reported that one human rights defender had received death threats and another was shot in the eye allegedly by a mine contractor and a former mine employee. The group reported violence near the mine site on February $28^{\text {th }}, 2011$ when mine supporters allegedly assaulted over a dozen people following a peaceful protest (Amnesty International 2012).

Yet, Goldcorp has a vested interest in building strong relationships with indigenous peoples globally. Subsequent to the 2010 HRA process, the relationships and dialog between Goldcorp and a variety of impacted groups, including indigenous peoples, around the Marlin mine have improved. Globally, the mining industry is striving for sustainability in its operations to improve corporate social responsibility (CSR) and obtain social license to mine (Sagebien et al. 2011). Sagebien et al. (2011) emphasize that mining companies are now expected to extend the benefits obtained through the extraction of finite resources by engaging in sustainable community investments that build human capital. This pressure to reframe conventional approaches to mining through enhanced CSR contributes to the political stream of the policy window. The requirements for consultation with local indigenous communities surrounding the Timmins Porcupine Gold Mine operations, combined with the company's interest in improving its relationship with indigenous peoples to improve CSR, provides a clear problem stream for this policy window.

\section{Focusing event}

The idea of a focusing event is used to describe a sudden, uncommon event such as a crisis that creates an opportunity for change (Birkland 1997, Michaels et al. 2006). In the Timmins case, a focusing event occurred in June 2010 when a female moose walked into the suspended Dome open pit mine. She was guided out of the mine but later returned to the pit and, after being sedated, she sadly died of exhaustion. From the local indigenous perspective, all things exist in relation to one another (Little Bear 2000, Wilson 2008). Through this lens, the moose's death had not been a random occurrence but rather was an important message regarding the implications of mining in the Timmins area, its impacts on human and environmental health broadly defined, and a reminder that the rights of future generations should be considered in current mining practices. Goldcorp, through the actions of its Indigenous Community Relations Manager Mary Boyden, acknowledged the loss and the potential intercultural crisis that would have likely ensued, and sought advice from local traditional practitioner Martin Millen. The moose's life was thus honored according to indigenous custom and protocol, as a result of the emerging partnership. 


\section{Solution stream: an emerging social innovation}

Through this process, Martin Millen and Mary Boyden formed a working partnership and began to realize the potential for further collaboration. They began with the realization that, like the female moose, the people of Timmins including the extensive indigenous population, were facing cumulative impacts of mining as a result of over 100 years of mining in the Timmins area. For instance, they realized that local indigenous peoples, who continue to practice indigenous ways, customs, and views or are attempting to relearn practices lost through colonization, may be collecting medicinal plants on potentially contaminated former mine sites all around Timmins. They recognized that two key factors provided a unique opportunity for change. These were the high price of gold and Goldcorp's interest in repairing its international reputation in dealing with local indigenous peoples. Martin Millen and Mary Boyden saw an opportunity for a new role for traditional Knowledge in local resource management and decision making. They also saw an opportunity for health and wellness in healing the land through restoration, rehabilitation, and monitoring; and healing individuals, communities, and intercultural relationships on physical, mental, emotional, and spiritual levels.

Finally, intercultural learning was determined to be a critical component of moving forward with Goldcorp, as this is viewed as a parallel and integral step in achieving respect and understanding of indigenous knowledge and traditional practices. The death of the female moose, although unfortunate, set the stage for a potential social innovation. A two-pronged strategy for change was initiated. First, negotiations with Goldcorp resulted in securing resources and support for the emerging initiative. Second, Martin Millen and Mary Boyden sought out recognized indigenous knowledge guardians and local indigenous governance institutions to acquire the necessary sanctioning to move forward with the initiative.

In collaboration with several indigenous knowledge guardians who were contacted through an informal network, advice was sought on how to interact with a corporate entity such as Goldcorp, and how best to use traditional ecological knowledge (TEK) in reclaiming a former mine site. The Coniaurum mine site in Timmins was operated from 1913-1961 when a major storm event caused a breach in the tailings dams, which resulted in a discharge of tailings and the shutdown of the operation (Goldcorp 2014). The Coniaurum site is one of the many legacy sites that Goldcorp had the responsibility to restore in the Timmins area and it has become the first fully rehabilitated site. From the start, Martin Millen and Mary Boyden understood that education plays a central role in this social innovation. Many indigenous peoples not currently practicing indigenous ways, customs, and views are in a stage of relearning and are engaged in restoring indigenous pedagogies, that is, how indigenous knowledge is learned and communicated, and the ways in which the pedagogy is carried out. Eventually, after several months of consultation with several indigenous knowledge guardians from across Canada-from Quebec to the foothills of the Rocky Mountains - an unprecedented partnership emerged. An opportunity was seen to not only heal the land by informing conventional mine rehabilitation efforts with TEK, but to begin to address, through an indigenous-led approach, the lasting effects of colonization, assimilation policies, and over 100 years of mining experienced by local indigenous peoples on physical, mental, emotional, and spiritual levels.

Further, it was recognized that this initiative could begin to heal the relationship between indigenous and nonindigenous peoples in the Timmins area, particularly within the mining industry. Therefore, the indigenous knowledge guardians committed to undertaking several indigenous pedagogical conferences at the Coniaurum site. The land is central indigenous pedagogy and, thus, the Coniaurum site itself, being physical space on the land in need of reclamation, is critical to hosting these conferences and to further the research on establishing the links between TEK and scientific knowledge within mine reclamation. To date, four major conferences have been held at the site: the "Whish-ki-yak-it," shaking tent gatherings in November 2010 and August 2011, and the "Whish-ki-yak-it Kinomaagaye-Gaamik" teaching lodge construction in October 2011 with subsequent gatherings in March 2012 and August 2012. Summarizing these conferences is well beyond the scope of this paper and wholly inappropriate from a cultural sensitivity and intellectual property perspective; however, several key insights are that: (1) the use of muskeg, an acidic soil type common in Arctic and boreal areas, on contaminated sites may help heal the land - this is based on traditional ceremonial knowledge; (2) there are risks associated with traditional medicinal harvesting practices adjacent to contaminated mining sites; (3) formal agreement must be struck with Goldcorp for this initiative to continue; (4) local youth must be engaged in the initiative; and (5) intercultural knowledge exchange is necessary to enhance mutual understanding of mine restoration, land use practices, community health and wellness as well as sustainability more broadly.

These insights have directly informed Goldcorp's rehabilitation strategy through experimental use of TEK, the company's approach to relations with indigenous peoples through the development of an emerging agreement, and the direction of the initiative itself. The positive impact of an ongoing intercultural knowledge exchange is demonstrated by the increased respect shown for indigenous knowledge, practices, and views demonstrated by Goldcorp in the Timmins context. Local indigenous youth have been engaged in each of the conferences, have been hired to prepare and maintain the facilities at the Coniaurum site, and have been involved in the extraction of nontimber forest products, e.g., wood for carving, construction of ceremonial structures, and ceremonial fires.

The goal is to foster a holistic initiative, based around the Elders' Advisory Council of AMAK and an intercultural, interdisciplinary support team that can help to build and sustain the initiative. Aside from securing conventional charitable foundation monies to keep the project going, the intent moving forward is to build on the momentum of the partnership and to develop a social enterprise that will offer for-profit services to mining companies that could include: traditional knowledge advisory services; intercultural education; community-based monitoring; and, nontimber forest product extraction. At the same time, it would offer not-for-profit services to local indigenous governance institutions, communities, and individuals that could include: traditional knowledge-informed resource management consultation to indigenous communities; traditional health practices and strategies to communities and individuals; 
local economic development advice and opportunities; and indigenous youth employment.

\section{DISCUSSION AND KEY FINDINGS}

Anishanaabe Maamwaye Aki Kiigayewin is an unprecedented initiative that can be seen as the convergence or "coupling" of interrelated problem, political, and solution streams sparked by a focusing event. This can be seen to represent or relate to the back loop of the panarchy or adaptive cycle, in that it represents the beginning of a collapse of the exploitative and oppressive mining regime typified by a century of mining activities in the Timmins area and Goldcorp's activities in Guatemala. Anishanaabe Maamwaye Aki Kiigayewin is addressing the negative effects of mining through TEK-informed reclamation services; Goldcorp is beginning to address the lasting effects of colonization by participating in indigenous pedagogical conferences and by exploring indigenous self-determination in the context of mining in Timmins. The development of AMAK has resulted in a reorganization of the system that is taking the form of an alternative system state-an emerging, mutually beneficial relationship between mining and indigenous peoples. Whether or not this emerging or potential social innovation can navigate the front loop and become an established innovation is yet to be seen.

Key findings from this work on the development of AMAK as a potential case of indigenous-led social innovation include:

- the role of key change agents or champions in identifying and taking advantage of the focusing event and policy window;

- the ability of the key change agents to humbly and respectfully identify their own limitations and recognize the need to involve, and use the knowledge of, influential and seminal traditional knowledge holders to appropriately inform this work as well as the willingness of these traditional knowledge holders to participate;

- the willingness of Goldcorp, at a management level, to take the risk required to meaningfully engage and support the work of traditional practitioners and traditional knowledge holders to begin a dialog and experiment with incorporating traditional knowledge into mine rehabilitation and restoration; and

- a common trust across all parties, including traditional knowledge holders, traditional practitioners, local community members, mining industry executives, managers and technicians, consultants, academic researchers, etc., in the value and importance of the work and the need for transformative change even though the outcomes are, as of yet, unknown.

In many ways, the true extent or impact of this emerging indigenous-led social innovation has yet to be realized. Once more fully realized, this work could set an important precedent for indigenous-corporate-government relations in the context of resource extraction. For instance, in the case of northern Ontario's emerging "ring of fire" mineral development, the effective and meaningful incorporation of traditional knowledge in mine planning and practice could have profound benefits for ensuring that this development is undertaken in the best way possible.
In relation to other documented cases of social innovation in the context of indigenous-corporate relations in resource extraction industries (such as Moore and Tjornbo 2012), the AMAK case is at a much earlier phase of development. Key lessons can be learned from Moore and Tjornbo's (2012) work on the case of the Great Bear Rainforest in terms of power relations; group, cross-sectoral, and intercultural relations; and the importance of understanding and taking advantage of key market mechanisms to influence change and innovation.

\section{NEXT STEPS}

For this potential indigenous peoples-led, collaborative social innovation to become established, existing research on case studies of social innovations (such as Westley et al. 2007, Westley and Antadze 2010) can be leveraged to develop strategies for moving forward. Work has already been initiated by members of the AMAK support team on the development of a business plan for this emerging social enterprise. Advice on the development of a prospectus and business plan is also being sought from representatives of Social Innovation Generation (SiG). SiG@MaRS was originally created to provide resources, that is, people, programs, physical facilities, funding, and networks to ensure that critical innovation in medical and related sciences happens. The SiG@MaRS team has extended their resources beyond medical sciences and technologies as they "stimulate, identify and harness great ideas, nurture their development and guide the transformation of those ideas into reality."

Preliminary efforts are being made to list the AMAK prospectus on the new Social Venture Exchange (SVX). The SVX is "a local, impact first market connecting social ventures, impact funds, and impact investors in order to catalyze new debt and equity investment capital for local ventures that have demonstrable social and/or environmental impact, including nonprofits, cooperatives, and for-profit corporations." The SVX is a new project of SiG@MaRS, in collaboration with TMX Group Inc., and supported by the Government of Ontario, Torys LLP, Causeway Social Finance, Imagine Canada, and many other partners. It is hoped that by creating a solid model for the social enterprise, the broad goals and projects of the initiative can be sustained and replicated. In the longer term, the AMAK initiative has the potential to empower, and be a vehicle for, local indigenous peoples and communities to restore indigenous pedagogies and become more involved in resource management decision making fora that have impacts on their traditional territories. Perhaps more importantly, AMAK can be a vehicle for healing the land, healing individuals and communities, and begin healing on an intercultural scale at physical, mental, emotional and spiritual levels.

\section{CONCLUSIONS}

Nowhere is the need for social innovation in Canada more acute than in the context of indigenous peoples. Whether it be in terms of income, education, social assistance, housing issues, or impacts from resource development, the social and environmental injustices against Canada's indigenous peoples are well documented (Statistics Canada 2006). Opportunities for social innovation that impact durability and scale can often take the form of policy windows (Kingdon and Thurber 1984, Kingdon 1995, Michaels et al. 2006) and be triggered by focusing events (Birkland 1997, Michaels et al. 2006). This kind of innovation 
process can be linked to the back loop dynamics of the panarchy or adaptive cycle (Biggs et al. 2010).

A policy window emerged in Timmins that was the result of the coupling of several streams of activity, including Goldcorp's purchase of a package of properties in the Timmins area; legislative and legal requirements for consultation with indigenous groups; the high price of gold; Goldcorp's need to improve its relations with indigenous peoples; and a unique group of indigenous knowledge guardians and a support team brought together as a result of the unfortunate death of a moose in an open-pit mine. Anishanaabe Maamwaye Aki Kiigayewin has emerged as a potential innovation to promote healing and rehabilitation of the land, and the physical, mental, emotional and spiritual healing of local indigenous peoples and communities, and to facilitate intercultural knowledge exchange to foster respect and understanding of indigenous knowledge, practices, and views. It also presents a unique opportunity to begin to heal the relationship between nonindigenous and indigenous peoples, particularly in the mining sector, in Timmins and across Canada.

The "Eighth Fire" is a sacred prophecy of the Nishnaabeg peoples that tells of a time when all humans will come together (Simpson 2008). At an annual event called "Gathering of Nations," in 2004, deceased William Commanda, an Algonquin Elder from the Maniwaki First Nation, announced that the Eighth Fire had been lit. However, it is up to human beings as to what intents they want to put into the Eighth Fire to benefit humanity, earth, water, and sky in a balanced relationship. The nonindigenous residents of Canada must "choose to change their ways, to decolonize their relationships with the land and indigenous nations, and to join with us ([indigenous] peoples) in building a sustainable future based upon mutual recognition, justice, and respect" (Simpson 2008:14). It is our belief that the AMAK social enterprise has the strong potential to contribute to the Eighth Fire and to be a model for a new relationship between nonindigenous and indigenous peoples living in Canada.

Responses to this article can be read online at: http://www.ecologyandsociety.org/issues/responses. $\mathrm{php} / 6771$

\begin{abstract}
Acknowledgments:
We would like to acknowledge the invaluable contributions of the indigenous knowledge holders and traditional practitioners associated with Anishanaabe Maamwaye Aki Kiigayewin that are our partners in this work as well as our friends. We wish to thank the employees of Goldcorp at Porcupine Gold Mines in Timmins, Ontario, Canada. Finally, we wish to acknowledge the support of the Social Sciences and Humanities Research Council of Canada (SSHRC).
\end{abstract}

\section{LITERATURE CITED}

Absolon, K. E. (Minogiizhigokwe). 2011. Kaandossiwin: how we come to know. Fernwood, Toronto, Ontario, Canada.

Amnesty International. 2012. Guatemala: lives and livelihoods at stake in mining conflict. Amnesty International, London, UK. [online] URL: http://www.amnesty.org/en/news/guatemala-livesand-livelihoods-stake-mining-conflict-2012-06-21

Armitage, D. R. 2005. Community-based narwhal management in Nunavut, Canada: change, uncertainty, and adaptation. Society and Natural Resources 18(8):715-731. http://dx.doi. org/10.1080/08941920591005124

Arthur, B. 2009. The nature of technology: what it is and how it evolves. The Free Press, New York, New York, USA.

Asch, M. and P. Macklem. 1991. Aboriginal rights and Canadian sovereignty: an essay on R. v. Sparrow. Alberta Law Review 29 (2):498-517.

Berkes, F., and C. Folke, editors. 1998. Linking social and ecological systems. Cambridge University Press, Cambridge, UK.

Berkes, F., J. Colding, and C. Folke. 2003. Navigating socialecological systems: building resilience for complexity and change. Cambridge University Press, Cambridge, UK. http://dx.doi. org/10.1017/CBO9780511541957

Biggs, R., F. R. Westley, and S. R. Carpenter. 2010. Navigating the back loop: fostering social innovation and transformation in ecosystem management. Ecology and Society 15(2): 9. [online] URL: http://www.ecologyandsociety.org/vol15/iss2/art9/

Birkland, T. A. 1997. After disaster: agenda setting, public policy, and focusing events. Georgetown University Press, Washington, D.C., USA.

Denzin, N. K., Y. S. Lincoln, and L. T. Smith, editors. 2008. Handbook of critical and indigenous methodologies. Sage, Thousand Oaks, California, USA.

GoldCorp. 2012. Our operations. GoldCorp, Toronto, Ontario, Canada. [online] URL: https://www.porcupinegoldmines.ca/en/ ouroperations/ouroperations.asp

Goldcorp. 2014. Case study: award-winning reclamation of the Coniaurum property. Goldcorp, Toronto, Ontario, Canada. [online] URL: http://www.goldcorp.com/English/ResponsibleMining/Partnerships-and-Programs/Mine-Closure-and-Reclamation/ default.aspx

Government of Ontario. 2006. Draft guidelines for ministries on consultation with Aboriginal peoples related to Aboriginal rights and treaty rights. Ontario Ministry of Aboriginal Affairs, Toronto, Ontario, Canada. [online] URL: http://www. aboriginalaffairs.gov.on.ca/english/policy/draftconsultjune2006.pdf

Gunderson, L. H., and C. S. Holling, editors. 2002. Panarchy: understanding transformations in human and natural systems. Island, Washington, D.C., USA.

Gunderson, L., C. S. Holling, and S. S. Light, editors. 1995. Barriers and bridges to the renewal of ecosystem and institutions. Columbia University Press, New York, New York, USA.

Haida Nation v British Columbia (Minister of Forests), [2004] 3 SCR 511, 2004 SCC 73. [online] URL: http://scc-csc.lexum.com/ scc-csc/scc-csc/en/item/2189/index.do

Heckenberg, R. 2011. Holding heart: Aboriginal breathing space in research epistemology. The International Journal of Interdisciplinary Social Sciences 5(9):107-118. 
Holling, C. S. 2001. Understanding the complexity of economic, ecological, and social systems. Ecosystems 4:390-405. http://dx. doi.org/10.1007/s10021-001-0101-5

Ibbitson, J. 2011. Native leaders commit to sweeping overhaul of reserve life. The Globe and Mail. 9 July, 2011. Toronto, Ontario, Canada. [online] URL: http://www.theglobeandmail.com/news/ politics/ottawa-native-leaders-commit-to-sweeping-overhaul-of-reserve$\underline{\text { life/article2053099/ }}$

Isaac, T. and A. Knox. 2003. The Crown's duty to consult Aboriginal people. Alberta Law Review 41:49-77.

Johnson, J. 2008. Kitchen table discourse: negotiating the tricky ground of indigenous research. The Landscape of Qualitative Research 32(3):127-137.

Jones, A., and K. Jenkins. 2008. Rethinking collaboration: working the indegenecolonizer hyphen. Pages 471-486 in N. K. Denzin, Y. S. Lincoln, and L. T. Smith, editors. Sage handbook of critical indigenous methodologies. Sage, Thousand Oaks, California, USA.

Kay, J. J., H. A. Regier, M. Boyle, and G. Francis. 1999. An ecosystem approach for sustainability: addressing the challenge of complexity. Environment 31:721-742.

Kingdon, J. W. 1995. Agendas, alternatives and public policies. Second edition. Harper Collins College, New York, New York, USA.

Kingdon, J. W., and J. A. Thurber. 1984. Agendas, alternatives, and public policies, volume 45. Little, Brown, Boston, Massachusetts, USA.

Kovach, M. E. 2010. Indigenous methodologies: characteristics, conversations, and contexts. University of Toronto Press, Toronto, Ontario, Canada.

Lawrence, S., and P. Macklem. 2000. From consultation to reconciliation: Aboriginal rights and the Crown's duty to consult. The Canadian Bar Review 79:252-279.

Legislative Assembly of Ontario. 2010a. Ontario Environmental Assessment Act, R.S.O. 1990, Chapter E.18. Toronto, Ontario, Canada.

Legislative Assembly of Ontario. 2010b. Mining Act, R. S. O. 2010, c. 18, s. 23. Toronto, Ontario, Canada.

Legislative Assembly of Ontario. 2012. Ontario Water Resources Act, R.S.O. 1990, Chapter O.40. Toronto, Ontario, Canada.

Levi-Strauss, C. 1962. La pensée sauvage. Plon, Paris, France.

Little Bear, L. 2000. Jagged worldviews colliding. Pages 77-85 in M. Battiste, editor. Reclaiming indigenous voice and vision. UBC Press, Vancouver, B.C., Canada.

McCarthy, D. D. P., D. D. Crandall, G. S. Whitelaw, Z. General, and L. J. S. Tsuji. 2011. A critical systems approach to social learning: building adaptive capacity in social, ecological, epistemological (SEE) systems. Ecology and Society 16(3): 18. [online] URL: http://www.ecologyandsociety.org/vol16/iss3/ $\underline{\operatorname{art18/}}$

McKeown, M. 2008. The truth about innovation. Prentice Hall, Old Tappan, New Jersey, USA.
Michaels, S., N. P. Goucher, and D. McCarthy. 2006. Policy windows, policy change, and organizational learning: watersheds in the evolution of watershed management. Environmental Management 38(6):983-92. http://dx.doi.org/10.1007/s00267-005-0269-0

Mining Watch. 2012. Introduction to the legal framework for mining in Canada. [online] URL: http://www.miningwatch.ca/ publications/introduction-legal-framework-mining-canada

Moore, M. L., and O. Tjornbo. 2012. From coastal timber supply area to Great Bear Rainforest: exploring power in a socialecological governance innovation. Ecology and Society 17(4): 26. http://dx.doi.org/10.5751/ES-05194-170426

Neuman, W. L. 2000. Social research methods: qualitative and quantitative approaches. Allyn and Bacon, Toronto, Ontario, Canada.

Office of the High Commissioner for Human Rights (OHCHR). 2011. Nineteenth and twentieth periodic reports of States parties due in 2009: Canada. Committee on the Elimination of Racial Discrimination (CERD), OHCHR, Geneva, Switzerland. [online] URL: http://tb.ohchr.org/default.aspx?country=ca

Pardy, B. and A. Stoehr. 2011. The failed reform of Ontario's mining laws. Journal of Environmental Law and Practice 23(1):115.

R. v Sparrow, [1990] 1 SCR 1075. [online] URL: http://scc-csc. lexum.com/scc-csc/scc-csc/en/item/609/index.do

Resilience Alliance. 2002. Resilience. Acadia University, Wolfville, Nova Scotia, Canada. [online] URL: http://www. resalliance.org/index.php/resilience

Rogers, E. M. 1995. Diffusion of innovations. Fourth edition. The Free Press, New York, New York, USA.

Sagebien, J., N. Lindsay, P. Campbell, and N. Smith. 2008. The corporate social responsibility of Canadian mining companies in Latin America: a systems perspective. Canadian Foreign Policy Journal 14(3):103-128. http://dx.doi.org/10.1080/11926422.2008.9673477

Simons, P., and L. Collins. 2010. Participatory rights in the Ontario mining sector: an international human rights perspective. International Journal Of Sustainable Development Law and Policy 6(2):177-216.

Simpson, L. 2008. Oshkimaadiziig, the new people. In L. Simpson, editor. Lighting the Eighth Fire: the liberation, resurgence, and protection of indigenous nations. Arbeiter Ring, Winnipeg, Manitoba, Canada.

Smith, L. T. 1999. Decolonizing methodologies: research and indigenous peoples. Zed, New York, New York, USA.

Solecki, W., and S. Michaels. 1994. Looking through the postdisaster policy window. Environmental Management 18(4): 587-595.

Statistics Canada. 2010. Aboriginal statistics at a glance. Statistics Canada, Ottawa, Ontario, Canada. [online] URL: http://www. statcan.gc.ca/pub/89-645-x/89-645-x2010001-eng.htm.

Steinhauer, E. 2002. Thoughts on an indigenous research methodology. Canadian Journal of Native Education 26(2):69-81. 
Taku River Tlingit First Nation v British Columbia (Project Assessment Director), [2004] 3 SCR 550, 2004 SCC 74. [online] URL: http://www.chiefs-of-ontario.org/sites/default/files/files/ taku\%20river\%20decision.pdf

Taylor, S. J., J. Steven, and R. Bogdan. 1984. Introduction to qualitative research methods. Wiley, New York, New York, USA.

Thurber, J. A. 2003. Foreword. In J. W. Kingdon, editor. Agendas, alternatives and public policies. Longman, New York, New York, USA .

Walker, B., L. Gunderson, A. Kinzig, C. Folke, S. Carpenter, and L. Schultz. 2006. A handful of heuristics and some propositions for understanding resilience in social-ecological systems. Ecology and Society 11(1): 13. [online] URL: http://www.ecologyandsociety. org/vol11/iss1/art13/

Walker, B. H., and D. Salt. 2006. Resilience thinking: sustaining ecosystems and people in a changing world. Island, Washington, D.C., USA.

Waltner-Toews, D., J. J. Kay, and N. M. E. Lister, editors. 2008. The ecosystem approach: complexity, uncertainty, and managing for sustainability. Columbia University Press, New York, New York, USA.

Westley, F. R. 2008. Renewal and resilience: the role of social innovation in building institutional resilience. African Health Sciences 8(SI):847.

Westley, F. R., B. Zimmerman, and M. Q. Patton. 2006. Getting to maybe: how the world is changed. Vintage, Toronto, Ontario, Canada.

Westley, F. R. and N. Antadze. 2010. Making a difference: strategies for scaling social innovation for greater impact. The Innovation Journal 15(2):1-20.

Whyte, W. F., editor. 1991. Participatory action research. Sage, Thousand Oaks, California, USA.

Wilson, S. 2008. Research is ceremony: indigenous research methods. Fernwood, Winnipeg, Manitoba, Canada.

Yin, R. K. 2009. Case study research: design and methods. Fourth edition. Sage, Thousand Oaks, California, USA

Young Foundation. 2006. Social innovation: what it is, why it matters, how it can be accelerated. Basingstoke, London, UK. 